\section{Current status of human rabies transmitted by dogs in Latin America}

\author{
Raiva humana transmitida por caninos: situação \\ atual na América Latina
}

${ }^{1}$ Veterinary Public Health Unit, Pan American Health Organization, Washington DC, U.S.A.

2 Surinam Office,

Pan American Health Organization, Washington DC, U.S.A.

3 Pan American Foot-andMouth Disease Center, Pan American Health Organization, Washington DC, U.S.A.

+ Deceased.

Correspondence M. C. Schneider Veterinary Public Health Unit, Pan American Health Organization. 525 23rd St. NW, Washington $D C$ 20037-2895. U.S.A. schneidc@paho.org

\begin{abstract}
Latin American countries made the political decision to eliminate human rabies transmitted by dogs by the year 2005. The purpose of the current study is to evaluate to what extent this goal has been reached. The epidemiological situation and control measures were analyzed and broken down within the countries by georeferencing. The 27 human cases reported in 2003 occurred in some $0.2 \%$ of the second-level geopolitical units (municipalities or counties) in the region, suggesting that the disease is a local problem. Several areas within the countries reported no more transmission of rabies in dogs. Nearly 1 million people potentially exposed to rabies received treatment. On average, 34,383 inhabitants per health post receive anti-rabies treatment (range: 4,300-148,043). Nearly 42 million dogs are vaccinated annually. Surveillance is considered fair according to the epidemiological criteria adopted by the study. Samples sent for rabies testing represent $0.05 \%$ of the estimated canine population (range: 0.001 to $0.2 \%$ ). The countries are quite close to achieving the goal.
\end{abstract}

Rabies; Dogs; Rabies Vaccines; Epidemiologic Surveillance

\author{
Maria Cristina Schneider 1 \\ Albino Belotto 1 \\ Maria Paz Adé 1 \\ Saskia Hendrickx 2 \\ Luis Fernando Leanes 3 \\ Maria José de Freitas Rodrigues 1 \\ Guilherme Medina 3 \\ Eduardo Correa ${ }^{\dagger}$
}

In 1983, the countries of the Americas, with support from the Pan American Health Organization (PAHO), pledged to eliminate human rabies transmitted by dogs 1 . The goal established was initially limited to the main cities and later extended to the entire Region, setting 2005 as the target date.

Since then, through the Regional Program for the Elimination of Human Rabies Transmitted by Dogs, the countries have made great efforts to reach the goal, with remarkable success $2,3,4,5$. In the last 20 years, the number of cases of human and canine rabies in the Region has dropped by nearly $90 \% 6$.

Eliminating human and canine rabies in the member states is a technical cooperation priority and key mandate for PAHO. To help analyze the extent to which the goal was reached, PAHO conducted a study entitled Elimination of Human Rabies Transmitted by Dogs in Latin America 7 to evaluate the rabies situation in the Region, resulting in this publication and a summary published in the PAHO Epidemiological Bulletin 8.

\section{Methodology}

PAHO developed standard methods ${ }^{9}$ and sent each participating country an interactive CDROM with the study methodology and a bibliography pertaining to the subject area. Countries also received a diskette with an Excel spreadsheet 
including a database broken down by first geopolitical level for each country to fill out. Filling out the database automatically generated the calculations and graphs.

\section{Study population}

All of the countries $(n=21)$ involved in the Regional Program for the Elimination of Rabies Transmitted by Dogs participated in the study: Argentina, Belize, Bolivia, Brazil, Chile, Colombia, Costa Rica, Cuba, Ecuador, El Salvador, Guatemala, Haiti, Honduras, Mexico, Nicaragua, Panama, Paraguay, Peru, the Dominican Republic, Uruguay, and Venezuela.

\section{Data source}

Data on cases of human and canine rabies recorded from 1990 to 2000 were obtained from the Epidemiological Surveillance System for Rabies (SIRVERA), coordinated by the Pan American Foot-and-Mouth Disease Center.

Country health authorities provided 20012003 data on Excel spreadsheets that were broken down according to the first geopolitical level (State, Department, or Province). Countries were also asked to report human cases at the second level (municipal). Analyses performed by each member state were sent in Excel files with interpretations in text form.

\section{Analysis}

Trend analyses covered the period from 1990 to 2003, while the other analyses included only the last three years of the study (2001-2003). Georeferencing was used to analyze: spatial distribution of human cases, epidemiological situation of canine rabies, post-exposure prophylaxis (PEP), canine vaccination, and epidemiological surveillance. To organize control measures, estimated means were derived from the 2001-2003 period for each first-level geopolitical unit, while mean, minimum, and maximum values were calculated for each variable at the country and regional level.

\section{Variables and indicators}

\section{- Recorded cases of human rabies transmitted by dogs}

Number of cases of human rabies transmitted by dogs recorded with clinical or laboratory diagnosis during a specific year for a given country, territory, or geographical area. If the viral variant of the rabies case was characterized and a variant other than V1 (dog) or V2 (dog/mongoose) was found, then the case was not included.

\section{- Recorded cases of canine rabies}

Number of cases of canine rabies recorded with clinical or laboratory diagnosis during a specific year for a given country, territory, or geographic area. If the viral variant of the case of canine rabies was characterized and a variant other than V1 (dog) or V2 (dog/mongoose) was found, then the case was not included.

\section{- Individuals examined in health services}

Number of individuals who went to health centers after being attacked by an animal.

\section{- Individuals treated}

Number of individuals who were examined and began post-exposure prophylaxis after being attacked by an animal that may have been a transmitter of rabies. PEP consists of administering serum and the vaccine dose indicated by the World Health Organization (WHO) protocol. There are still countries in the region that continue to employ the suckling mouse brain vaccine (CRL) for human use, and some do not administer serum.

\section{- Percentage of individuals treated vs. examined}

Number of individuals receiving PEP for human rabies vs. number examined after an animal attack, per 100 .

\section{- Number of health posts with treatment}

Health posts that offer PEP to individuals attacked by animals that may be rabies transmitters.

\section{- Index of health posts with treatment per inhabitants}

Health units with PEP in relation to the number of inhabitants in a first-level geographic unit, per 1,000 .

\section{- Number of dogs vaccinated}

Number of dogs vaccinated against rabies in a first-level geopolitical unit.

\section{- Vaccination coverage}

Number of dogs vaccinated in relation to the estimated canine population $(10 \%$ of the human 
population if more precise information is not available), per 100 .

\section{- Number of canine samples sent}

Total number of canine brain samples sent to the diagnostic laboratory per year in that first-level geopolitical unit. According to Schneider 10 in the study in Brazil, the minimum number of samples sent for proper epidemiological surveillance was nearly $0.2 \%$ of the estimated canine population. For the purposes of this study, samples representing $0.1 \%$ of the estimated canine population per year were defined as sufficient.

\section{- Epidemiological surveillance criteria}

Excellent: samples $\geq 0.1 \%$ of the estimated canine population sent annually. Fair: $0.09 \%$ to $0.01 \%$. No surveillance (silent): samples sent $<0.01 \%$ canine population.

There are areas in Latin America where the technical rabies control authorities state that canine rabies variants one and two (V1 and V2) have not circulated for many years. In these cases the number of samples is often smaller.

\section{- Criteria for defining the epidemiological situation}

The epidemiological situations with respect to canine rabies V1 and V2 in Latin America are the following: group 1 - no canine-to-canine rabies virus transmission (circulation of V1 and V2) for more than 10 years and surveillance is reliable according to the respective National Rabies Program Director; group 2 - no cases reported in humans or dogs, and epidemiological surveillance is excellent; group 3 - no cases reported in humans or dogs, and epidemiological surveillance is fair; group 4 - no cases reported in humans or dogs, but the area is believed to lack rabies epidemiological surveillance (silent areas); and group 5 - virus still circulating among humans or dogs; reports of one or more cases of canine rabies or human rabies transmitted by dogs from 2001 to 2003.

\section{Results}

\section{Epidemiological situation}

Analysis of the trend for 1990-2003 shows a decrease in the number of cases of human rabies transmitted by various species, from 251 to 35 (86\%) (Figure 1). Dogs account for $65 \%$ of all cases with information on the attacking animal.
As shown in Figure 1, human rabies transmitted by dogs basically accounted for that reduction, with the annual number of cases decreasing from 152 to 27 . The number of cases of human rabies transmitted by wildlife ( $75 \%$ of which are attributable to bats) changed, but there was no downward trend.

Human rabies transmitted by dogs is currently very localized in Latin America. In 2003, 27 cases were reported in the 21 countries included in the study (mortality rate $=0.005$ per 100,000 inhabitants). In six countries (27\%), cases of variants one and two (V1 and V2) of human rabies transmitted by dogs were recorded. There were two cases in Bolivia, or 0.023/100,000 inhabitants; 14 cases in Brazil, or 0.008/100,000; five cases in El Salvador, or 0.077/100,000; three cases in Haiti, or 0.036/100,000; one case in Mexico, or $0.001 / 100,000$; and two cases in Venezuela, or $0.008 / 100,000$.

Breaking down the unit of analysis, rabies was present in 15 (3.6\%) of the 414 first-level geopolitical units (States, Departments, or Provinces) and in only $21(0.23 \%)$ of the nearly $10,500 \mathrm{sec}$ ond-level geopolitical units (equivalent to municipalities in most of the countries) in Latin America. Most of those geopolitical units were the same ones that had recorded cases in 2001 and 2002 (Figure 2). The areas with the highest concentration of cases were from low-income outskirts of large cities like Port-au-Prince, Haiti; San Salvador, El Salvador; and Fortaleza, Ceará State, Brazil.

As for canine rabies, 1,131 cases (V1 and V2) were reported in 2003 in 12 countries (55\%). However, as in the human cases, breaking down the geopolitical units (States, Provinces, or Departments), rabies was reported in 68 (16.4\%) of the 414 first-level geopolitical units (Figure 3). More cases were observed in some States in Northeast Brazil, like Bahia; in the Jujuy Province in Northern Argentina on the border with Bolivia; and in the State of Zulia, Venezuela.

Based on the methodological criteria, a map was drawn (Figure 4) that reflects the epidemiological situation of canine rabies in the first-level units of Latin American countries. More than 10 years ago, most of the Southern Cone was free of canine rabies (group 1), i.e., all of Chile and Uruguay, most of Argentina, and all of South/Southeast Brazil, including the States of São Paulo and Rio de Janeiro. Panama, Costa Rica, and some Departments in Peru are also included in Group 1.

A significant part of Latin America is in Groups 2 and 3, where no cases were recorded in 2001-2003 and epidemiological surveillance exists, as in Peru and Mexico, two areas that will probably shift to Group 1 in a few years. In 


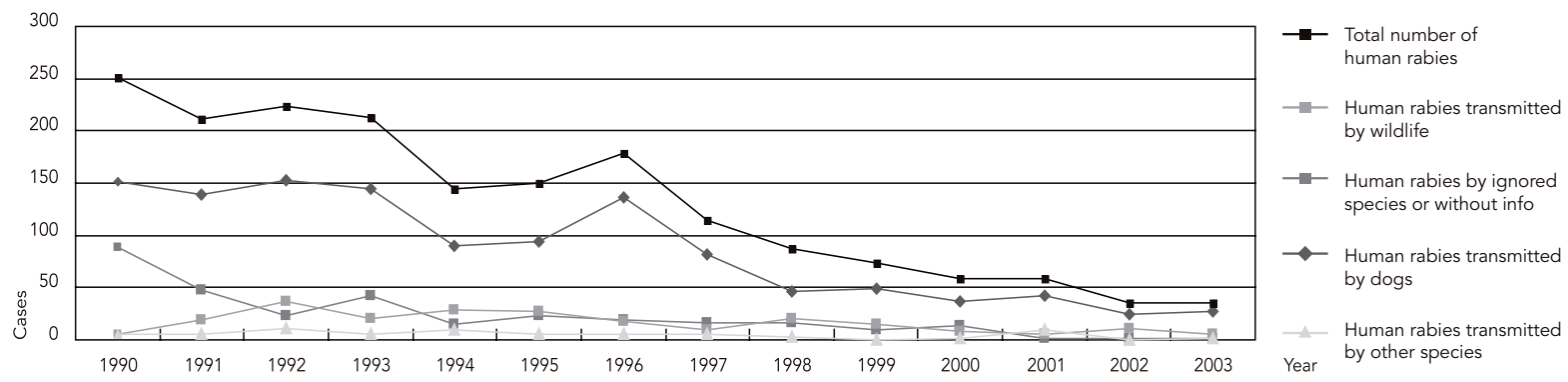

Source: Pan American Health Organization 9.

Group 5, where the virus is still circulating in the canine population, there are several areas in which the intensity of transmission is quite low, with very few cases reported during the period and good surveillance, as in the case of several units in Mexico and Peru. Other units still show more intense transmission, as illustrated in Figure 3. The situation is quite troubling in the areas classified as Group 4, where there is no epidemiological surveillance, and where some of the areas are close to units with the virus circulating in the canine population.

\section{Control measures}

The main prevention and control activities for human rabies transmitted by dogs advocated by the Regional Program for Elimination of Rabies in Latin America focus on providing appropriate treatment of people potentially at risk of acquiring the disease (pre- and post-exposure prophylaxis), mass vaccination of dogs, and epidemiological surveillance.

\section{- Treatment for exposed individuals}

Nearly 1 million individuals presumably at risk of rabies infection (mostly due to attacks by animals, usually dogs) are treated annually in Latin America (an average of 961,195 during the period). In most Latin American countries, very few receive pre-exposure prophylaxis. As a proxy for analyzing access by individuals exposed to risk, the number of health posts with treatment available was analyzed in relation to the number of inhabitants. In Latin American countries with information, the average was 34,383 inhabitants per health post with rabies treatment (range: 4,300-148,043 inhabitants). As shown in Figure 5 , national variations by first-level geopolitical unit are minimal in most of the countries. The majority (70.2\%) of the Provinces or States show a maximum of 100,000 inhabitants per health post with PEP. Post-exposure prophylaxis is less available in some of the Southern Cone units, possibly because rabies no longer poses a major threat in that area.

During the period analyzed (2001-2003), an average of $25.4 \%$ of individuals examined in health services in Latin America received PEP (range: $3.2 \%$ to $58.4 \%$ ) (Figure 6). Significant differences in PEP are observed from country to country and within countries at the first geopolitical level.

\section{- Canine vaccination}

Nearly 42 million dogs are vaccinated annually in Latin America (an average of 42,168,802 dogs during the period). Most vaccinated animals (75\%) are from Brazil (17 million) and Mexico (16 million), with the largest canine populations in Latin America and excellent vaccination coverage.

The Regional Program recommends vaccinating $80 \%$ of the estimated canine population. Some countries have come close to $100 \%$ coverage, while others are below the $60 \%$ mark. Figure 7 only shows coverage in first-level units where rabies cases occurred from 2001 to 2003, with an average of $81 \%$ (range: $23.2 \%$ to $100 \%$ ). A vast area surpassed the goal of $80 \%$, which includes most States of Brazil and Mexico and a few from other countries. However, several areas still 
Figure 2

Cases of human rabies transmitted by dogs. Latin America, 2001- 2003.

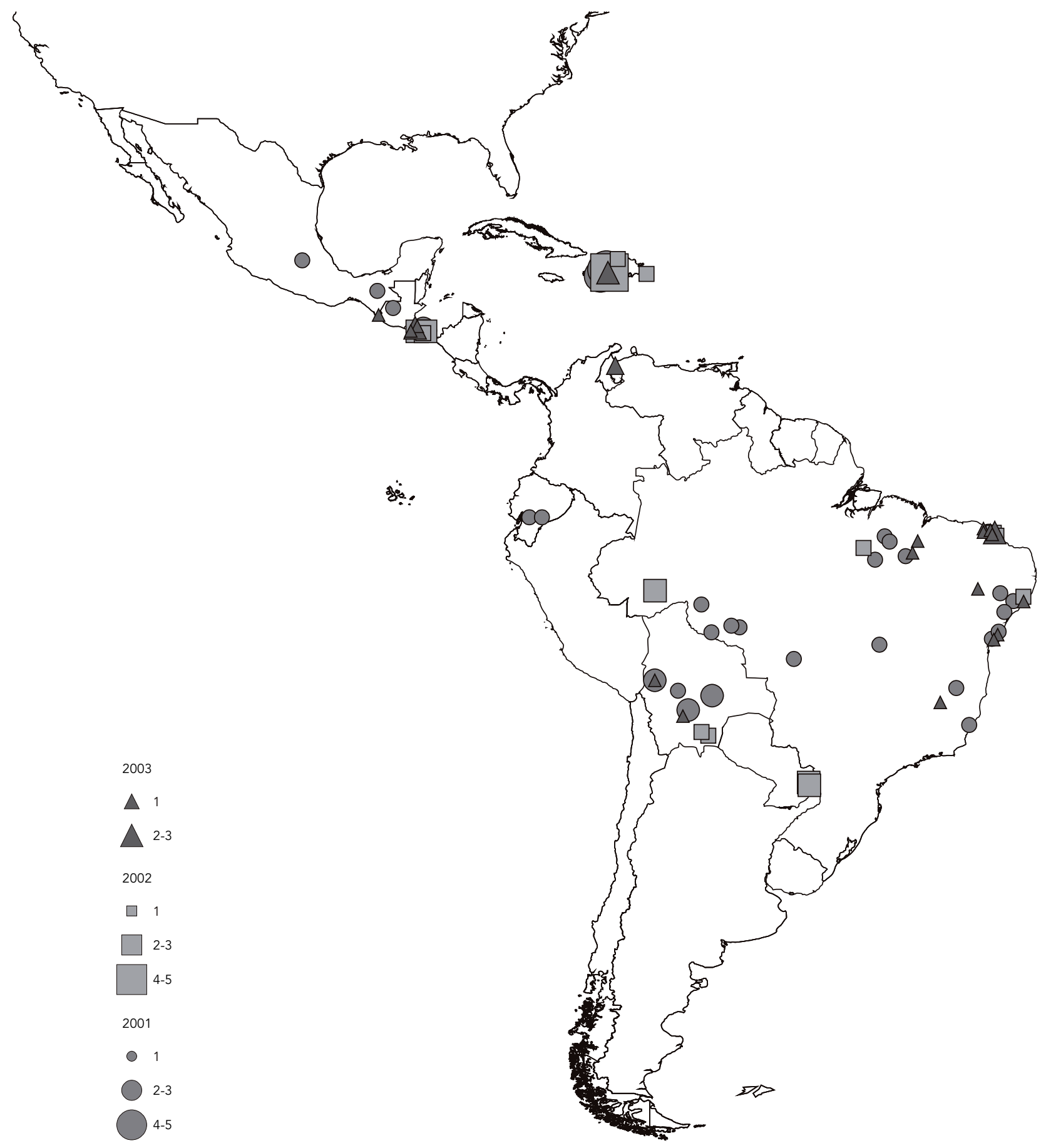


Figure 3

\section{Cases of canine rabies. Latin America, 2003.}

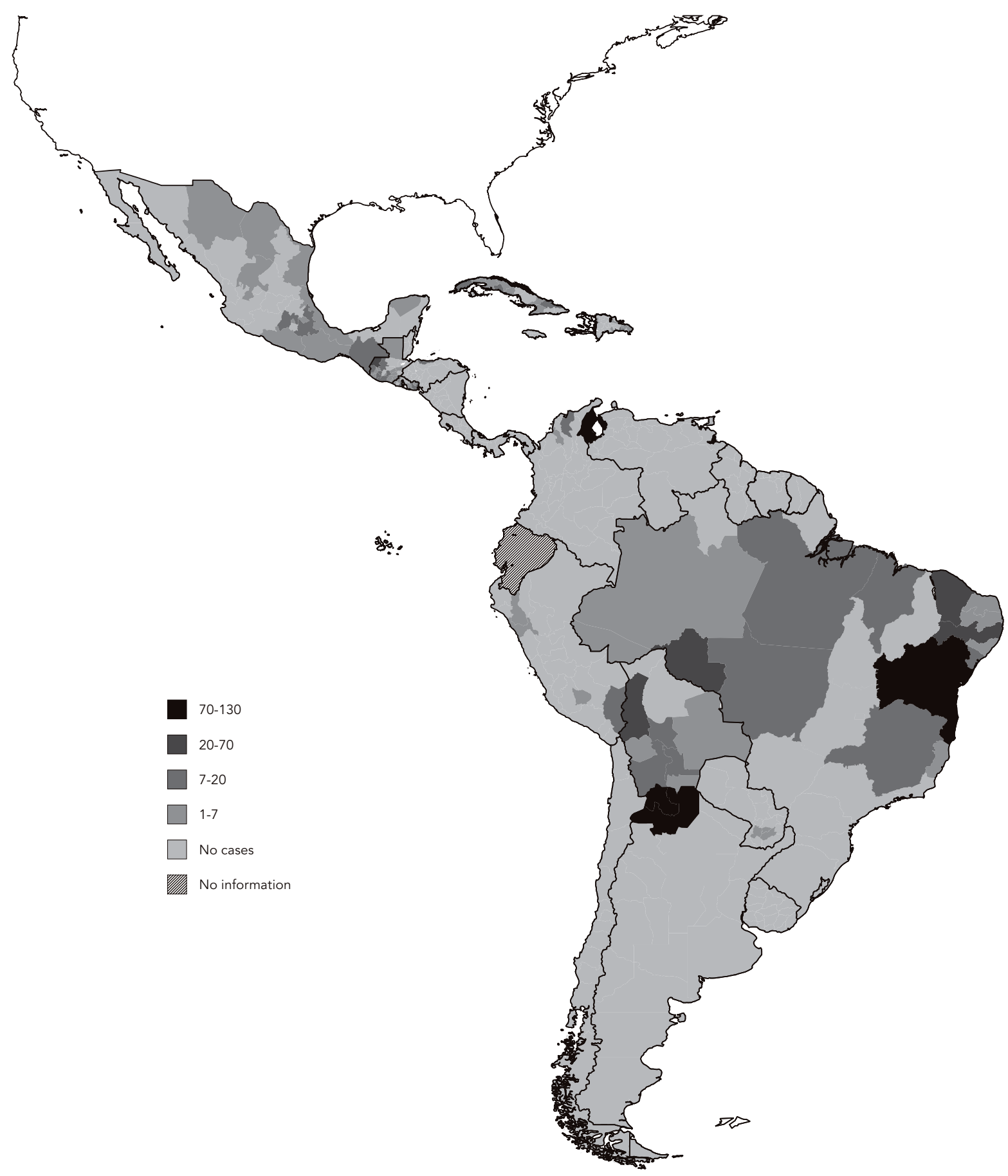


Figure 4

Epidemiological situation of canine rabies. Latin America, 2001-2003.

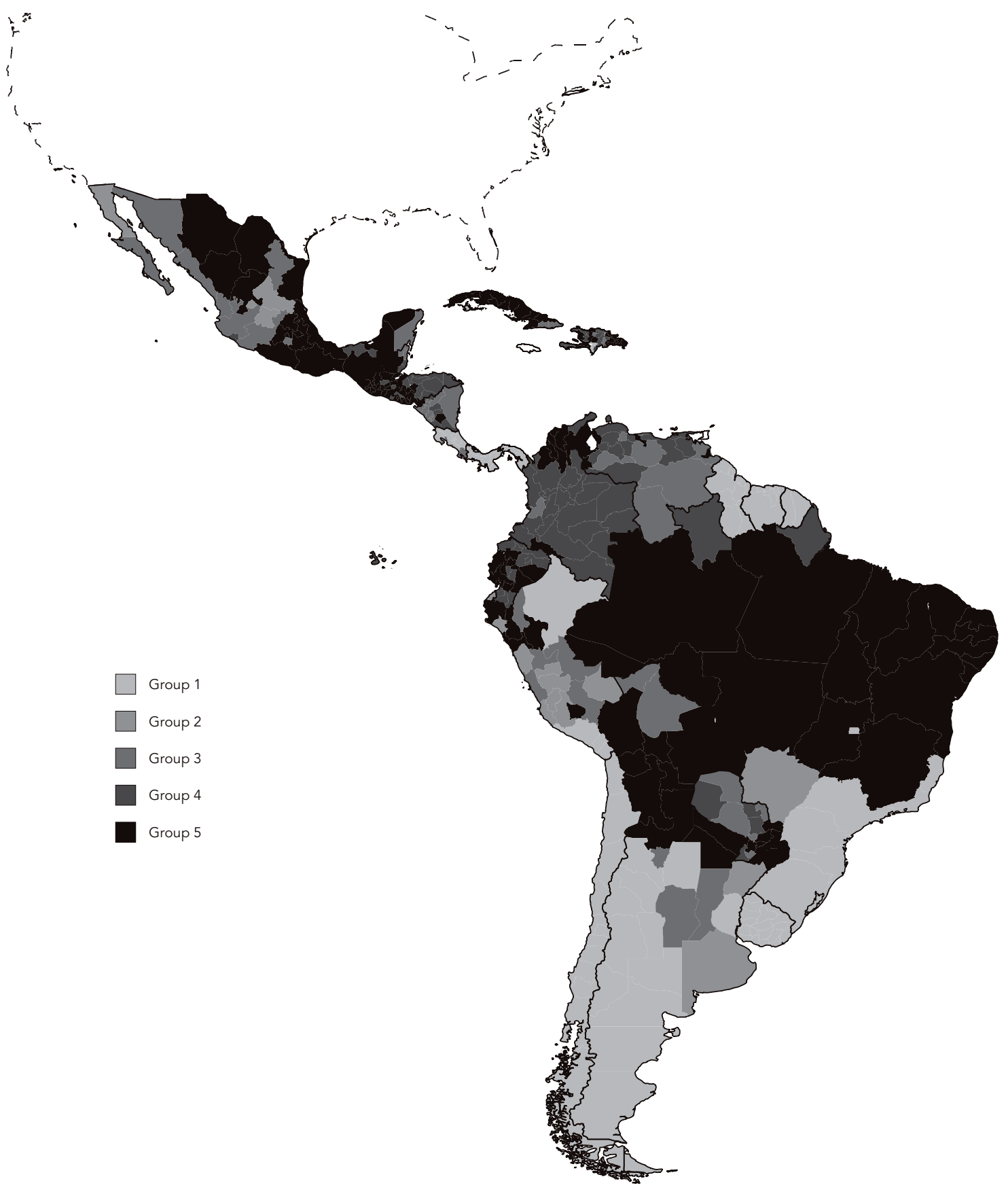


Figure 5

Health posts with rabies post-exposure prophylaxis for humans. Latin America, 2001-2003.

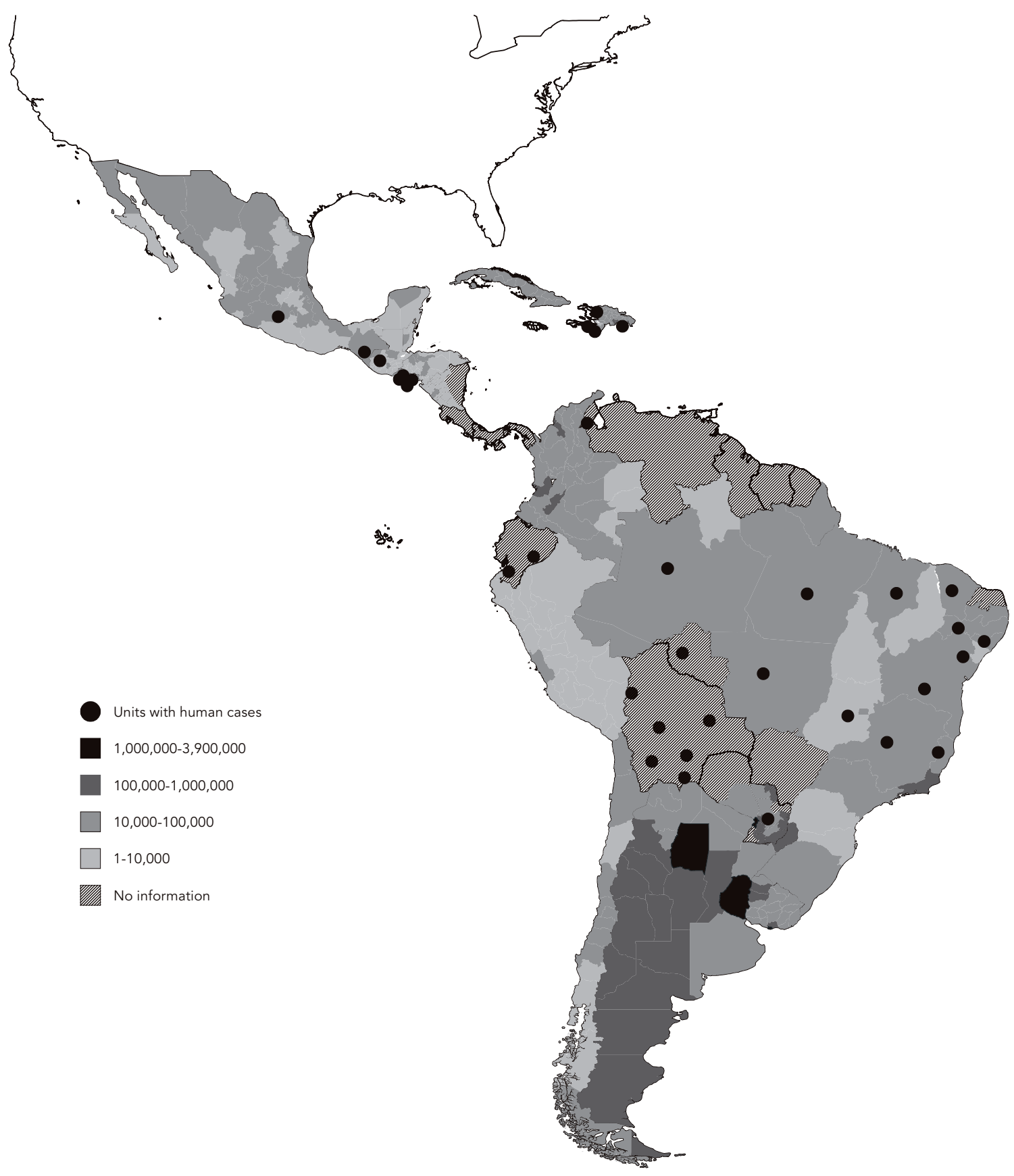




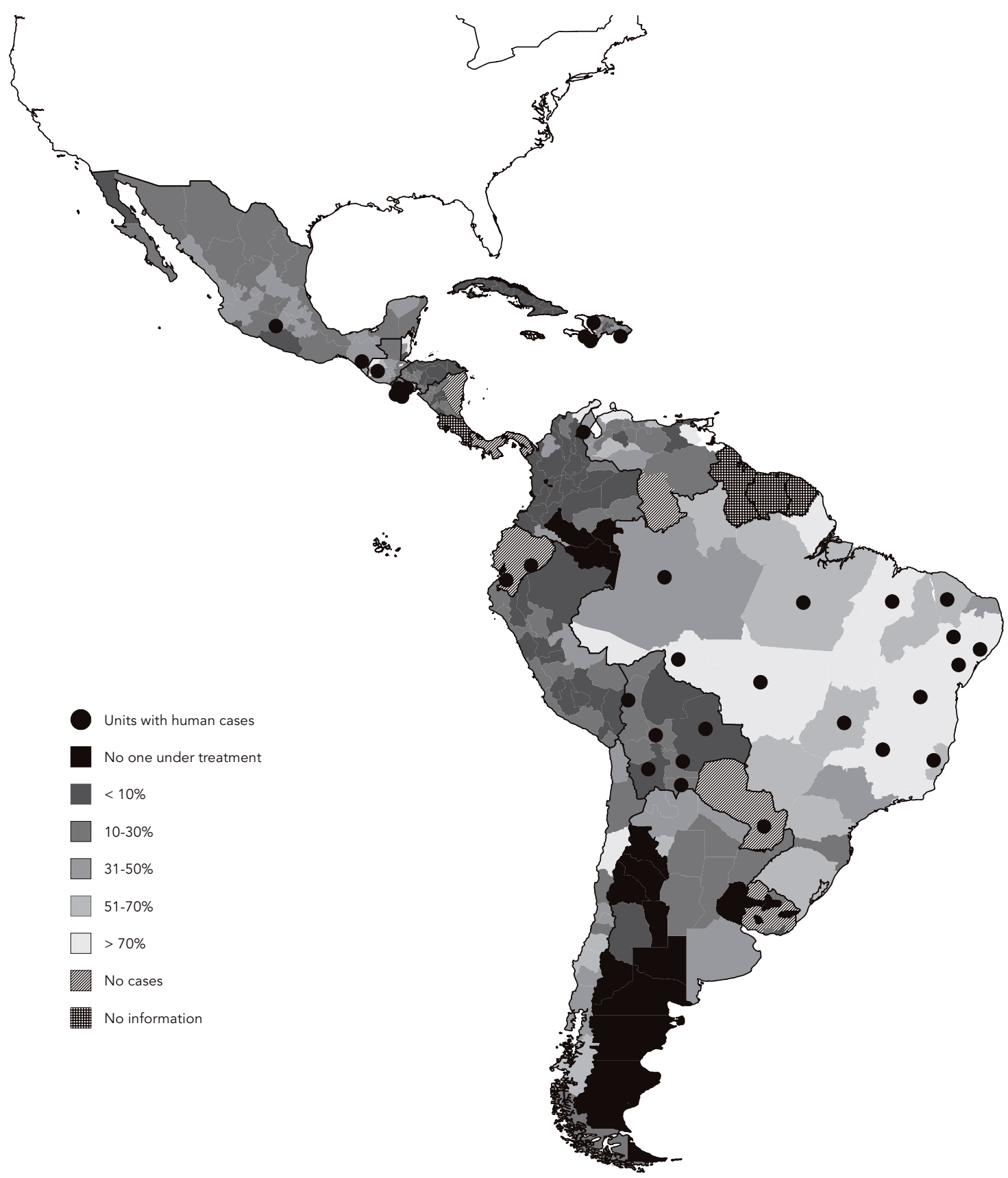


Figure 7

Vaccination coverage at the first geopolitical level with rabies cases. Latin America, 2001-2003.

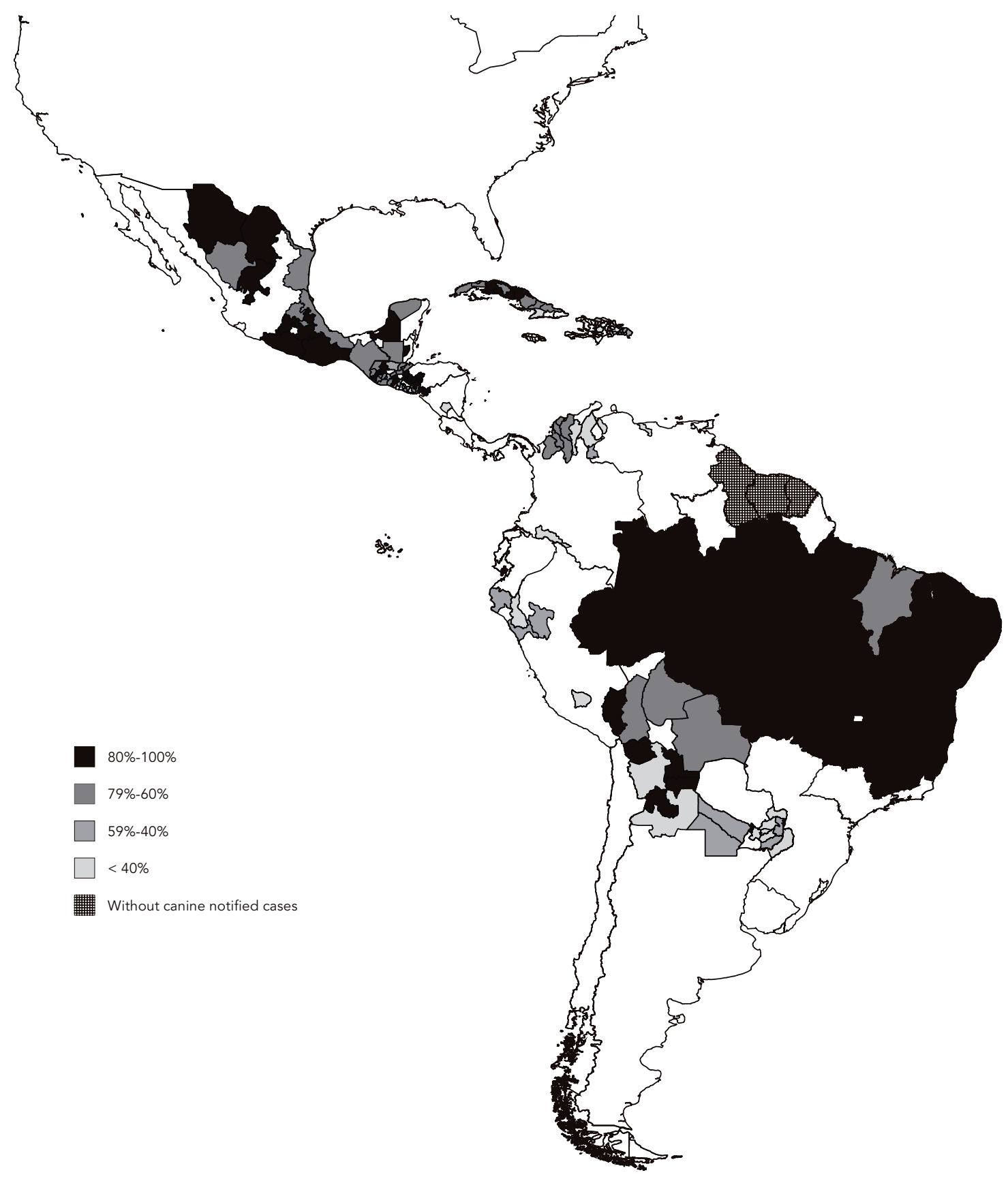


display alarmingly low coverage, some with less than $40 \%$.

Some countries or geopolitical units within countries no longer hold mass vaccination campaigns, as is in Group 1 (> 10 years without rabies, and with reliable information).

\section{- Epidemiological surveillance}

On average, 73,752 canine samples were processed for rabies diagnosis in the region. Some 138 laboratories in Latin America test for the disease, half of which are located in Brazil and Mexico. In Peru, Argentina, Colombia, Cuba, and Ecuador diagnosis is also decentralized, and there are laboratories around the respective countries.

The methodological criteria were used to analyze epidemiological surveillance. Generally speaking, rabies epidemiological surveillance is quite good in the countries, since four (Mexico, Brazil, Argentina, and Peru) exceed the national average of sending samples from $0.1 \%$ of the canine population (suggested as a quality parameter). Analyzing this information broken down by first-level units (Figure 8), Peru, Bolivia, nearly all of Brazil, Mexico, most of Chile and Argentina, and some units in other countries appear to have reliable epidemiological surveillance based on this criterion. The mean number of samples submitted for analysis was $0.05 \%$ (range: 0.001 to $0.2 \%$ ) of the region's estimated canine population.

In Central American countries like Costa Rica and Panama that already have the disease under control, the number of samples is minimal, although the virus is still circulating in the canine population in neighboring countries.

The situation is worrisome in some Andean countries, mainly Ecuador, Colombia, and parts of Venezuela, where percentages of sample analysis are very low both in units with and without canine cases.

\section{Discussion}

The experience in Latin American countries that in the past 20 years have managed to reduce cases of human and canine rabies by approximately 90\% with support from PAHO proves that the disease can be controlled with effective action. The governments made the political decision to eliminate the disease and have allocated human and financial resources to meet the goal, placing rabies on their public policy agendas. Thus, rabies cannot be considered a neglected zoonosis in the region.

As indicated in this study, the 27 recorded cases of human rabies transmitted by dogs in
Latin America in 2003 occurred in only $0.2 \%$ of the second-level units (municipalities); while canine rabies was reported in $16.4 \%$ of the firstlevel units (States, Departments, or Provinces). This suggests that the disease is currently highly localized, thus suggesting that if the countries define their priority areas and intensify control measures, it is quite likely that the disease will be eliminated in the short run.

Importantly, part of Latin America has already managed to eliminate rabies virus circulation from the canine population. A large portion of the Southern Cone, including all of Chile and Uruguay, vast areas of Argentina, and all of southern Brazil, is already free of canine rabies, in addition to Panama, Costa Rica, and some Departments in Peru ${ }^{8}$. The achievements in these areas must be sustained. The necessary control and surveillance measures for eliminating rabies presuppose the continuity of political, technical, and budgetary support.

While human rabies transmitted by dogs is under control, rabies transmitted by wildlife (mainly bats) has assumed greater epidemiological importance and thus poses a challenge. Human rabies transmitted by wildlife requires other control strategies that are more complex and intersectoral 11 .

Latin America is the most unequal region in the world in terms of income distribution, clearly reflected in the inhabitants' living and health conditions 12. Some Latin American countries have an annual per capita gross national income (according to purchasing power parity) of approximately US $\$ 10,000$, while for others the figure is closer to US $\$ 1,600$. Nearly $11 \%$ of Latin America's population lies below the international poverty line, but with major differences between countries (ranging from $45 \%$ in some to $2 \%$ in others) 13 .

The profile of several diseases, including rabies, reflects this pattern of inequalities. Most cases of human rabies transmitted by dogs in the past three years have occurred in low-income areas on the outskirts of large cities, with more stray dogs that are missed by the vaccination campaigns. Furthermore, the low-income residents' harsh living and working conditions make it difficult for them to obtain treatment for themselves or their children, although rabies treatment is free in most Latin American countries.

Figure 7 on vaccination coverage in areas reporting cases of canine rabies indicates that there are still units with low coverage of the canine population, suggesting that this control measure is not applied as recommended. Canine vaccination is the most important action for interrupting circulation of the virus among the canine popula- 
Figure 8

Rabies surveillance. Latin America, 2001-2003.

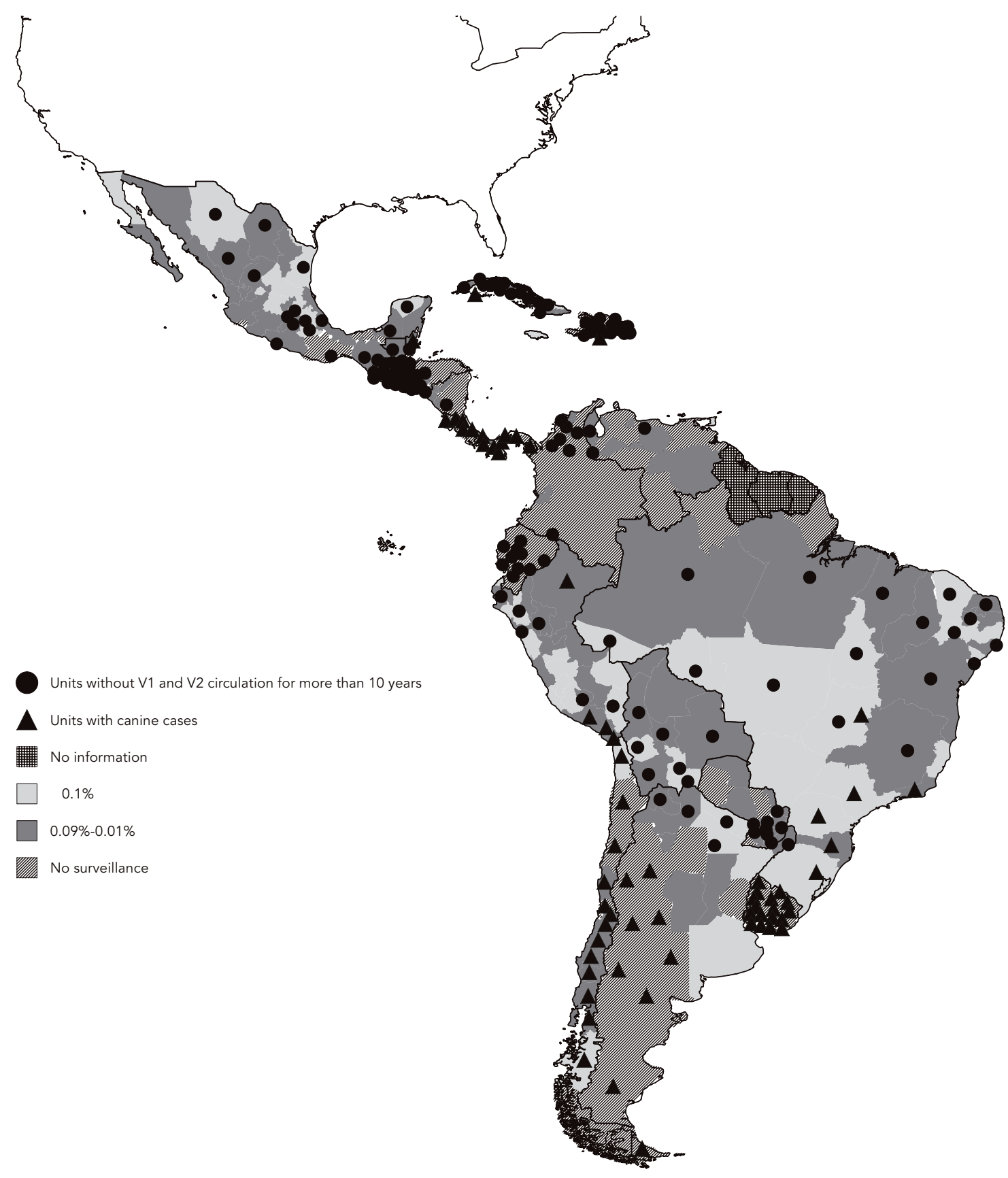


tion and is a key measure for areas with reported cases. To keep the virus from circulating among dogs, it is necessary to maintain good long-term coverage. If coverage is interrupted, the disease reemerges. It is also important to analyze the vaccination coverage in smaller geopolitical areas within States in order to identify municipalities with potentially low coverage, where the virus could circulate more readily in the canine population. This could be one reason why canine cases are still reported in States with overall high coverage rates.

Post-exposure rabies prophylaxis is decentralized to the State, Provincial, or Department level in most Latin American countries. The availability of free PEP at health services in Latin American countries is doubtless an important factor in the reduction of the number of human cases. In high-risk areas where canine cases occur, rabies cases in the human population could be avoided if people were well informed and received guidance about prophylactic measures, assuming that such was available. For example, during outbreaks in Northern Argentina there were numerous canine cases, and no reported human cases. National programs must step up their educational and communication activities for this purpose.

There are significant differences between and within the countries in terms of the ratio of individuals treated to those seen in health services. This indicator should be studied together with the epidemiological situation; in areas without rabies, PEP could be recommended for a limited number of people, thus avoiding unnecessary treatment. However, in areas where canine rabies does exist, rabies PEP percentages well below the regional average are worrisome, since they could suggest that there are individuals at risk who are not receiving treatment.
Epidemiological surveillance is currently essential for rabies control in Latin America. Nearly half of the countries have a fair surveillance system according to the study criteria, analyzing the country as a geopolitical unit. It is believed that in most areas, most canine rabies cases are reported, even if epidemiological surveillance is low due to certain clinical aspects of the disease in dogs. Some countries, like Haiti, experience major difficulties in improving the surveillance of animals. This is probably why some areas reported canine cases without having a good surveillance system, as in some areas of Andes. In this case, risk of the disease is known to persist, and attention should focus on the development of control measures to eliminate the disease, like vaccinating the canine population.

The surveillance system is even more important when canine cases are no longer reported, as a way to increase confidence that rabies is not present in the canine population. Several studies have discussed methodologies to evaluate rabies risk 10,14, 15, all of which prioritize surveillance.

Several extensive areas no longer have any cases of canine rabies, despite persistence of the diseases in dogs in neighboring territories. Stepping up epidemiological surveillance along border areas is thus a key issue for national agendas (along with the each country's internal risk).

The availability of proven rabies control strategies for decades and the successful experiences in the majority of Latin American countries, in addition to historical solidarity between countries through support from the scientific community, allow all of us to expect that the goal of eliminating human rabies transmitted by dogs in Latin America may soon be reached. 


\section{Resumo}

Os países da América Latina tomaram a decisão política de eliminar a raiva humana transmitida por cão até 2005, e o objetivo deste estudo é analisar o cumprimento desta meta. A situação epidemiológica e as ações de controle foram analisadas de forma desagregada dentro dos países, utilizando-se georreferenciamento da informação. Os 27 casos humanos relatados em 2003 ocorreram em cerca de 0,2\% das unidades de segundo nível geopolítico (municípios) da região. Esse dado sugere que a doença atualmente é muito localizada. Vários países não reportam mais transmissão de raiva em cães. Cerca de 1 milhão de pessoas são potencialmente expostas ao risco da raiva e recebem atendimento médico. Existem em média 34.383 (classe: 4.300-148.043) habitantes por posto de saúde com tratamento anti-rábico. São vacinados cerca de $42 \mathrm{mi}$ lhões de cães anualmente, 70\% deles no Brasil e México. A vigilância epidemiológica para a raiva foi considerada média pelos critérios estabelecidos no estudo, sendo enviada $0,05 \%$ da população canina estimada de amostras para diagnostico de raiva. Foi considerado que os países estão muito próximos de alcançar a meta.

Raiva; Cães; Vacinas Anti-Rábicas; Vigilância Epidemiológica

\section{Contributors}

M. C. Schneider coordinated the study, drafting of the text, data analysis, and final review. A. Belotto conducted the final review. M. P. Adé performed data collection and analysis and participated in the written text, data review, graphs, and final review. S. Hendrickx performed data collection. L. F. Leanes revised the manuscript. M. J. F. Rodrigues revised and edited the manuscript. G. Medina produced the graphs and maps. E. Correa participated in the final review.

\section{Acknowledgements}

This study was made possible through collaboration from different agencies and individuals both at PAHO and other collaborating institutions. It was conducted jointly with the Directors of various National Rabies Control Programs, in collaboration with PAHO Country Representatives. Much of the information for this report came from an earlier PAHO publication that cites all of the individual contributors: Eliminación de la Rabia Humana Transmitida por Perros en América Latina (ISBN 927532574). The authors of the current paper wish to acknowledge the importance of this detailed publication. They would also like to acknowledge the contributions of various current PAHO staff members as well as national rabies control personnel. Their comments and suggestions are greatly appreciated. The authors especially wish to acknowledge the contributions of Patricia Nareja who prepared all the GIS maps in the new format requested by the journal.

\section{References}

1. Organización Panamericana de la Salud. Estrategia y plan de acción para la eliminación de la rabia humana en América Latina para el final de la década 1980. Guayaquil: Organización Panamericana de la Salud; 1983.

2. Schneider MC, Almeida GA, Souza LM, Moraes NB, Diaz RC. Controle da raiva no Brasil: 1980 a 1990. Rev Saúde Pública 1996; 30:196-203.

3. Montebello LR, Luna EJA, Carmo EH, Oliveira RC, Oliveira D, Sihler C, et al. The epidemiological situation of rabies in Brazil. In: Proceedings of the XV International Conference on Rabies in the Americas. Santo Domingo: Internatinal Conference Rabies in the Americas; 2004. p. 18-9.

4. Navarro-Vela AM. Plan de eliminación de la rabia humana transmitida por perros en el Perú avances. In: Proceedings of the XV International Conference Rabies in the Americas. Santo Domingo: Internatinal Conference Rabies in the Americas; 2004 . p. 24-5.

5 Secretaría de Salud de México. La rabia en México 1988-1993. Salud Pública Méx 2004; 36:462-6.

6. Belotto A, Leanes LF, Schneider MC, Tamayo H, Correa E. Overview of rabies in the Americas. Virus Res 2005; 111:5-12.

7. Organización Panamericana de la Salud. Eliminación de la rabia humana transmitida por perros en América Latina. Washington DC: Pan American Health Organization; 2005. 
8. Schneider MC, Belotto A, Adé MP, Leanes LF, Correa E, Tamayo H, et al. Situación epidemiológica de la rabia humana transmitida por perros en América Latina en 2004. Boletín Epidemiológico/OPS $2005 ; 26: 2-4$.

9. Organización Panamericana de la Salud. Evaluación de la meta para el 2005 de la eliminación de la rabia humana transmitida por perros en América Latina: metodología para la evaluación. Washington DC: Organización Panamericana de la Salud; 2004.

10. Schneider MC. Estudo de avaliação sobre área de risco para a raiva no Brasil [Master's Thesis]. Rio de Janeiro: Escola Nacional de Saúde Pública, Fundação Oswaldo Cruz; 1990.

11. Schneider MC. Rabia humana transmitida por murciélago hematófago en Brasil: modelo de transmisión y acciones de control [PhD Thesis]. México DF: Instituto Nacional de Salud Pública; 1996.
12. Deininger K, Squire L. A new data set measuring income inequality. World Bank Econ Rev 1996; 10:565-91.

13. Pan American Health Organization. Health situation in the Americas: basic indicators. Washington DC: Pan American Health Organization; 2004.

14. Organización Panamericana de la Salud. Reunión de consulta de expertos sobre las bases técnicas para el reconocimiento de áreas libres de rabia y requisitos de cuarentena animal. Santo Domingo: Organización Panamericana de la Salud; 1994.

15. Secretaría de Salud de México. Criterios para la certificación de áreas geográficas que han logrado la eliminación de la transmisión de la rabia canina. México DF: Secretaría de Salud de México; 2005.

Submitted on 20/Mar/2006

Final version resubmitted on 26/Mar/2007 Approved on 29/Mar/2007 